\title{
REDESCRIPTION OF PSEUDOLEPIDAPEDON BALISTIS MANTER, 1940 AND A BIOLOGICAL VARIANT (TREMATODA: ACANTHOCOLPIDAE) FROM THE RED SEA FISHS; BALISTOIDES VIRIDESCENS AND RHINECANTHUS ASSASI. \\ By
}

REFAAT MA KHALIFA ${ }^{1}$, HEMELY ABDEL-SHAFY HASSAN ${ }^{2}$, HODA SAADY MOHAMADAIN ${ }^{2}$ AND YASSER FARHAT MAHMOUD KARAR ${ }^{2}$ Department of Medical Parasitology, Faculty of Medicine, Assiut University ${ }^{1}$, Department of Zoology, Faculty of Science, Qena, South Valley University ${ }^{2}$ Correspondence: rkhalifa eg@yahoo.com and dr_hodasm60@yahoo.com

\begin{abstract}
During a survey of Red Sea fish parasites, two trematodes belonging to the genus Pseudolepidapedon Yamaguti, 1938 were encountered: P. balistisManter, 1940 was found in the small intestine of the fish Balistoidesviridescens and was redescribed for the first time from Egypt; adding many detailed morphological and ultrastructural characters. The second trematode was found in the small intestine of the fish Rhinecanthusassasi and found to represent a biological variant of the previous species as it differs from it in its generally smaller dimensions, shape of suckers and pharynx and the testes. SEM details of the first species were described for the first time illustrating the differences in the spination and papillae on different parts of the body; which may be of taxonomic importance in recognizing future different species of the genus.
\end{abstract}

Keywords: Pseudolepidepadonbalistis, Balistoidesviridescens, biological variant, Rhinecanthusassasi, Red Sea fish

\section{Introduction}

Studies on the helminth parasites of the Red Sea fishes tend to be limited to short reports describing new taxa. Previous stud-ies on trematodes of the subclass Digenea in the region included the pioneer works of Nagaty between the 1930s and 1970s, Parukhin and Abdel-Aal in 1970s, Saoud and Ramadan in the 1970s; 1980s, Overst-reet in 1980s and Shalaby and Hassanaine since the 1990s (Redaet al, 2005).

The present study deals with two newly described trematodes belonging to family Pseudolepidapedon Yamaguti, 1938: AcanthocolpidaeLuhe 1906; from the Red Sea fishes.

Acanthocolpids are parasites of marine fishes, occasionally of sea snakes. They are characterized by spinous tegument, the lack of external seminal vesicle and the presence of a uterine terminal receptacle (Jones et al, 2005) and the concept of PseudolepidapedonYarnaguti, 1938 is based mainly on the type-species, $P$. paralichthydisYamaguti, 1938

Materials and Methods

Fishes were caught from Sharm El-Naga (Safaga, Red Sea) and kept on ice until examined under a dissecting microscope. They were identified by keys of Lieske and Meyers (1994) and Randall et al. (1990). The entire alimentary canal and the surrounding peritoneal cavity were examined. Encountered worms were collected alive, washed in saline, fixed in cold AFA (alcohol-formalin-acetic acid) under slight cover glass pressure (Garcia andAsh, 1979), washed in distilled water, rinsed in $70 \%$ ethanol, stained with alum carmine, destained in diluted $\mathrm{HCl}$, dehydrated in ascending concentrations of ethanol, cleared in clove oil, and mounted in DPX. Prevalence and worm burden were estimated according to definitions given by Bush et al. (1997). The measurements were expressed in micrometers. Drawings were prepared by the Camera Lucida (PZO 01852 10x). Ultra- 
structure of the parasite was studied by Scanning Electron Microscope (SEM).

\section{Results}

1) Pseudolepidapedon balistis Manter, 1940

(Fig.1). Family: AcanthocolpidaeLühe, 1906. Subfamily: PseudolepidapedinaeYamaguti, 1971,

Genus:Pseudolepidapedon Yamaguti,1938Sp

ecies: Pseudolepidapedon balistisManter, 1940,

Prevalence: $2 / 2=100 \%$; worm burden: $4-7$ worms per infected fish.

Fish host:Balistoidesviridescens.

Description (based on 5 mature worms; measurements (Tabs. 1, 2\& 3): The living specimens were slightly pink in color and with sluggish movement. Body was clubshaped to pyriform completely spined. Posterior end broadly rounded, anterior end more tapering. Greatest width was near posterior end under testicular level. Tegument was armed with simple spines of two types; the first type was two rows of large oral spines. The second type was shorter and surrounding almost the whole body. Oral sucker was ovoidal to oblate, sub-terminal, with sub-terminal oral aperture. Prepharynx long and dilated at its posterior end to fit in wide pharynx which was barrel-shaped and the anterior third provided with circular muscles forming a prepharyngeal ring. Esophagus was very short. The intestinal bifurcation was in mid-fore body. Ceca were flask-shaped, wide, diverging laterally and terminating at level of posterior end blindly. Acetabulum was pre-equatorial, situated at level of intestinal bifurcation and clearly larger than oral sucker. Genital pore was median, immedia-tely anterior to acetabulum. The seminal receptacle was absent. Laurer's canal not observed and the uterine seminal receptacle was somewhat clear. Testes were two in number, ovoid, smooth or with slightly irregular contour, tandem or slightly diago-nal, close together, intercecal, in posterior half of body. Ovary was semiovoid, un-lobed, pretesticular, slightly to the right, just median to right cecum and conti- guous with anterior testis. Uterus was preovarian, inter-caecal and to the left of ovary, extending to left side of ventral sucker. Ootype was com-plex and anterior to the ovary. Eggs were elongate translucent, oval, thin-shelled and operculated. Vitellinefolicles were large, extend from intestinal bifurcation to post-eriorbodyend, dorsal, ventral, and lateral to ceca, confluent posterior to testes and dorsally between acetabulum and pharynx. They were extending over the esophagus and may cover the lower edge of the pharynx. Excretory vesicle was I-shaped with terminal aperture.

Ultrastructure: SEM examination showed that the body was surroundby different-sized spines throughout its length (Plate1,A) with characteristically two rows of elonga-ted finger-like crown-shaped circle of spines on the top of the oral sucker; surrounding the mouth opening (Plate1,B). These spines possess rough surfaces with many transverse furrows and formed of shorter row anteriorly and a longer one posteriorly (Plate1,C).

Magnification of oral sucker papillae showed that they were equal-sized and sessile; distributed randomly around the muscular portion (Plate1,D). Oral sucker was formed of a layer of transverse muscle fibers surrounded by circular fibers (Plate1,E). Anterior part of the body was character-ized by dense dome-like spines (Plate1,F) followed by dense irregularly tapering spines with broad ends on the middle part of the body (Plate1,G). Multipointed short spines with 3-4 finger-like termination were condensed on the posterior third of the body (Plate1,H) while the hind part of the body was equipped with fewer scattered spines with more prominent fingerlike termina-tions (Plate1,I).

2) Pseudolepidapedon balistis (Biological Variant;Fig. 2).

Prevalence; 2/13 (15.4\%); worm burden: 2 per infected fish.

Fish host: Rhinecanthusassasi

Description: Living specimens were fleshy with the slight pink color and with sluggish 
movement.Body was oblong, closelycylindrical, and plump. Maximum breadth was at level of ovary and the anterior testis, body tapering anteriorly and rounded at its posterior extremity. Tegument was thick, beset throughout its length with well developed, scale-like spines of two types; the first type was large oral spines, the second type was the body spines which were shorter and arranged in rows which were crowded and most numerous at the anterior extremity and become gradually distant at the posterior extremity with somewhat few numbers. A pair of inconspicuous eye-spots was present. Oral sucker was finger-bowlshaped to oblate, sub-terminal, with subterminal oral aperture. Prepharynx was long, entirely below the oralsucker and dilated at its posterior end to fit in wide pharynx. Pharynx was ovoidal; not provided with prepharyngeal ring. Esophagus was very short and wide. The intestinal bifurcation was in mid-fore body. Ceca were flaskshaped, simple, gradually widened posteriorly, diverging laterally and terminating close to each other at posterior extremity. Acetabulum with sphincter around aperture, pre-equatorial at anterior part of middle ofthebody, situated at level of intestinal bifurcation and was clearly larger than the oral. Genital pore was median immediately anterior to the acetabulum and between the upper part of the ventral sucker and the intestinal bifurcation. The seminal receptacle was absent, Laurer's canal was not clearly observed. Cirrus sac elongate, more or less divided by a narrowed region into a fairly wide anterior portion lying along the left anterior border of acetabulum and a claviform posterior portion extending to ovary and overlapping that organ slightly dorsally. Ovary was ovoidal, unlobed, pretesticular, slightly to the right, (just postequatorial) just median to right cecum and contiguous to anterior border of anterior testis (anterodextral). The two testes were ovoidal, with slightly irregular contour, tandem or diagonal, close together, intercecal, in posterior half of body and the opposite nearby edges of each testis may overlap with each other. The anterior testis was wider, smaller and kidney-shaped while the posterior testis was longer, larger and ovoid. Vitelline follicles were large, extremely crowded, extending from intestinal bifurcation to posterior end of body, dorsal, ventral, and lateral to ceca, confluent posterior to testes and anteriorly between acetabulum and pharynx. Also, they extend over the esophagus and may cover the lower edge of the pharynx. Excretory pore was terminal. Excretory vesicle was Ishaped (tubular), extending below the posterior testis, with terminal pore. Uterus was large saccular, preovarian, fully engorged with mature eggs, intercaecal and to the left of ovary, extending to left of ventral sucker. Eggs were elongate oval, thin-shelled, operculated and translucent. Ootype was complex and anterior to the ovary. Cirrus sac was long and slender, curving and extending from below ventral sucker to above of acetabulum.

\section{Discussion}

1) Pseudolepidapedon balistis Manter,1940: The present authors reckon that there are 11 marine species satisfying the present criteria used by Bray (2005) to define the genus, including one of the Pseudolepidapedon species described by Yamaguti (1938). The dimensions, measurements and ratios of the present specimens compared with those of Pseudolepidapedonbalistis of the other previous works showing that the investigated samples were similar morphometriccally toPseudolepidapedonbalistis, mainly in the ratio of the suckers, esophagus length, body spines length and egg dimensions.

On the other hand, the measurements of the current worms having a slight higher values than those of the previous works especially; body length, prepharynx length, pharynx dimensions, the obvious large size of ventral sucker, ovary width, anterior testis length and post-testicular distance. Thedifferences may be biological due to the difference in hosts or methods of study. 
Manter (1940) stated in his original description that there were two eye spots but current specimens were lacking these structures. Besides, he said that acetabulum was only slightly larger than oral sucker while the present measurements showed that the acetabulum was obviously larger than oral sucker. Also, Manter (1940) stated the presence of seminal receptacle while the subsequent re-description of $P$. balistis made by Caballero and Caballero (1952), Bravo-Hollis (1956), Manter (1963), Mago and Chinchilla (2002) and the current research indicated the absence of seminal receptacle.

Revising the previous works on that parasite indicated that its ultrastructure was described for the first time illustrating many details which may be of great taxonomic importance to be used in differentiating different species of this genus. Moreover, Pseudolepidapedonbalistis was recorded in Egypt for the first time, thereby increasing the geographic range of the species and was recorded in the fishBalistoidesviridescensas a new host record for the parasite. This raises the question; why the present samples have a slightly high scale of measurements, dimensions and ratios than that of the other previous descriptions of this parasite.. The answer can be traced to the parasite that has a higher ability to adjust and adapt within this host or other. On the other hand, the present host could be the original definitive host for this parasite.

2) Pseudolepidapedon balistis (Biological variant): By applying Bray keys (Bray, 2005) to identify the specimens, and found that this parasite belongs to Pseudolepidapedon (Yamaguti, 1938) and the comparisons among the current specimens and the available other species of this genus, it was found that the main morphological features of the current biological variant were very similar to those of the present re-description of Pseudolepidapedon balistis with the following differences in the current specimens: In spite of being generally smaller in measurements, they have a bigger prepharynx- length, pharynx width and ventral sucker to ovary length. The presence of two eye spots around the esophagus which indicates the young age of specimens. The body was semi cylindrical and its maximum width was at the ovarian level. Shape of the oral sucker and pharynx were different. Also, specimens had an elongated saccular uterus fully engorged with more condensed mature eggs indicating a high rate of fecundity in apparently young worms. The anterior testis was clearly wider than the posterior. The eggsize was characteristically smaller.

\section{Conclusion}

The worms were found in another final host (Rhinecanthusassasi). However, the present differences are not enough to create a new variety of the redescribed species and we preferred to describe it as a biological variant; with the fish Rhinecanthusassasi a new host record for the parasite.

\section{References}

Bravo-Hollis, M, 1956:Tremátodos de pecesmarinos de aguasmexicanas. XI. Estudio de 17 digéneos de la costa delPacífico, incluyendoseis species nuevas y ungéneronuevo. An. Inst. Biol. 22, 1:245-77.

Bray, RA, 2005: Family AcanthocolpidaeLühe, 1906. In: Keys to the TrematodaA. Jones, R.A. Bray \& D.I. Gibson (Eds.) Vol.2. CABI Publishing; Wallingford and the Natural History $\mathrm{Mu}-$ seum, London.

Bray, RA, Cribb, TH, Barker, SC,1996: Cabieiapudican. sp. (Digcnea: Acanthocolpidae) from monacanthid fishes of the southern Great Barrier Reef, Australia. Parasite 3:49-54.

Bush, AO, Lafferty, KD, Lotz, JM, Shostak, AW, 1997: Parasitology meets ecology on its own terms: Margolis et al. revisited. J.Parasitol. 83:575-83.

Caballero S, Caballero, E, 1952:Revisión de los géneros y species queintegran la familiaAcanthocolpidaeLühe, 1909. Re Med Vector Parasitol, 11, 1/2:1-230.

Garcia,LS, Ash,LR,1979: Diagnostic Parasitology: Clinical Laboratory Manual. $2^{\text {nd }} E d$. London: The C.V. Mosby Company.

Jones,A, Bray, RA, Gibson, DI, 2005: Keys of Trematoda, Vol 2. CABI: Publishing and the National History Museum, London. 
Lieske, E, Myers, R, 1994: Collins PocketGuide,. Coral reef fishes: Caribbean, Indian Ocean, , and Pacific Ocean including the Red Sea. $1^{\text {st }}$ Ed. London: Harper Collins.

Mago, YM, Chinchilla, OL,2002:Finding ofApocreadiumfoliatum (Siddiqi\& Cable, 1960) overstreet, 1969 (Apocreadiidae: Apocreadiinae) andPseudolepidapedonbalistis Manter, 1940 (Lepocreadiidae: Pseudolepidapedinae) in fishes from Mochima Bay, state of Sucre, Venezuela. Biomedicina14, 1:105-12.

Manter, HW, 1940: Digenetic trematodes of fishes from the Galapagos Islands and the neighboring Pacific. Allan Hanc. Pacif.Exped. 2, 14: 325-497.

Manter HW. 1963: Studies of digenetic trematodes of fishes of Fiji. III. Families Acanthocolpidae, Fellodistomidae and Cryptogonimidae. Parasitol, 49, 3:443-50
Parukhin, AM, 1978: Studies on trematodafauna of the Indian and Atlantic Ocean fishes. Biol.Morya. Kiev.45:90-9.

Randall, JE, Allen, GR, Steene, RC, 1990: Fishes of the Great Barrier Reef and Coral Sea. University of Hawaii Press, Honolulu, Hawaii.

Reda, M, Hassanaine,EIS, Gibson, DI, 2005: Trematodes of Red Sea fishes: Hexangium brayi n sp. (AngiodictyidaeLooss, 1902) and Siphoderaaegyptensisn.sp. (Cryptogonimidae Ward, 1917) with a review of their genera. Syst.Parasitol. 61:215-22.

Yamaguti, S, 1938: Studies on the helminthfauna of Japan. Part 21-Trematodes of Fishes, IV. SatyûYamaguti, Kyoto 139.

Yamaguti, S, 1971: Synopsis of the digenetic trematodes of vertebrates. Vol I\&II, Keigaku Publishing Co., Tokyo. 
Table 1: Dimensions, measurements and ratios of Pseudolepidapedon balistis.

\begin{tabular}{|c|c|c|c|c|c|c|c|}
\hline Dimension \& Measurements $(\mu \mathrm{m})$ & Min. & Max. & Mean & Ratios & Min. & Max. & Mean \\
\hline Length & 2479 & 3200 & 2840 & Width \%* & 31 & 39 & 35 \\
\hline Width (Widest region) & 968 & 1006 & 987 & Fore body \%* & 32 & 34 & 33 \\
\hline Width at level of: & & & & Hind body length \%* & 51 & 53 & 52 \\
\hline - Under oral sucker directly & 375 & 453 & 414 & Sucker length ratio & $1: 2.34$ & $1: 2.99$ & $1: 2.67$ \\
\hline - Ventral sucker & 772 & 807 & 790 & Sucker width ratio & $1: 1.21$ & $1: 1.21$ & $1: 1.21$ \\
\hline - Ovary & 925 & 951 & 938 & Oral sucker length\%* & 5 & 5 & 5 \\
\hline - Anterior testis & 951 & 981 & 966 & Ventral sucker length\%* & 13 & 16 & 15 \\
\hline - Posterior testis & 946 & 955 & 951 & Oral sucker length/Width ratio & 1:1.81 & $1: 2.17$ & 1:1.99 \\
\hline Fore body length & 848 & 1019 & 934 & Ventral sucker length/Width ratio & 1:0.88 & 1:0.95 & 1:0.92 \\
\hline Hind body length & 1274 & 1702 & 1488 & Sucker total length\%** & 18 & 21 & 20 \\
\hline Oral sucker length & 132 & 175 & 154 & Oral sucker length/Pharynx length ratio & $1: 2.13$ & $1: 2.77$ & $1: 2.45$ \\
\hline Oral sucker width & 286 & 317 & 302 & Ventral sucker length/ Pharynx length ratio & 1:0.91 & 1:0.92 & 1:0.92 \\
\hline Prepharynx length & 162 & 230 & 196 & Prepharynx length\%** & 7 & 7 & 7 \\
\hline Pharynx length & 365 & 372 & 369 & Pharynx length\%* & 12 & 15 & 14 \\
\hline Pharynx width & 231 & 325 & 278 & Anterior testis length\%* & 10 & 13 & 12 \\
\hline Esophagus length & 16 & 27 & 22 & Anterior testis length/ Width ratio & 1:0.98 & 1:0.76 & 1:0.85 \\
\hline Precaecal sacs & 0 & 0 & 0 & Posterior testis length $\% *$ & 13 & 14 & 14 \\
\hline Intestinal bifurcation to ventral sucker & 46 & 162 & 104 & Posterior testis length/Width ratio & $1: 0.71$ & 1:0.81 & 1:0.77 \\
\hline Genital pore to ventral sucker & 0 & 3 & 12 & Ovary length\%* & 6 & 7 & 7 \\
\hline Ventral sucker length & 395 & 409 & 402 & Ovary length/Width ratio & $1: 1.31$ & $1: 1.73$ & $1: 1.34$ \\
\hline Ventral sucker width & 347 & 387 & 367 & Ventral sucker to ovary \%* & 8 & 10 & 9 \\
\hline Ventral sucker to ovary & 188 & 313 & 251 & Distance between testes\%* & 0.3 & 0.3 & 0.3 \\
\hline Ovary length & 173 & 203 & 188 & Post-testicular distance $\% *$ & 13 & 14 & 14 \\
\hline Ovary width & 229 & 266 & 248 & Prepharynx distance $\% *$ & 12 & 12 & 12 \\
\hline Ovary to anterior testis & 3 & 9 & 6 & Prebifurcation distance $\% *$ & 26 & 28 & 27 \\
\hline Anterior testis length & 249 & 412 & 331 & Oral to ventral sucker distance $\% *$ & 37 & 37 & 37 \\
\hline Anterior testis width & 243 & 318 & 281 & Previtelline distance $\% *$ & 22 & 24 & 23 \\
\hline Distance between testes & 7 & 10 & 9 & Pre-genital pore distance $\% *$ & 29 & 29 & 29 \\
\hline Posterior testis length & 311 & 455 & 383 & Preovarian distance \%* & 53 & 54 & 54 \\
\hline Posterior testis width & 221 & 369 & 295 & Post-uterine distance $\% *$ & 42 & 42 & 42 \\
\hline Post-testicular distance & 344 & 456 & 400 & \multirow[t]{12}{*}{ Intestinal caeca length\%* } & \multirow[t]{12}{*}{68} & \multirow[t]{12}{*}{72} & \multirow[t]{12}{*}{70} \\
\hline Post-vitelline region length & 18 & 33 & 26 & & & & \\
\hline Egg length & 68 & 81 & 75 & & & & \\
\hline Egg width & 41 & 50 & 46 & & & & \\
\hline Prepharyngeal distance & 305 & 372 & 339 & & & & \\
\hline Prebifurcal distance & 682 & 785 & 7334 & & & & \\
\hline Oral to ventral sucker distance & 928 & 1194 & 1061 & & & & \\
\hline Pre-genital pore distance & 723 & 914 & 819 & & & & \\
\hline Previtelline distance & 538 & 763 & 651 & & & & \\
\hline Preovarian distance & 1302 & 1737 & 1520 & & & & \\
\hline Post-uterine distance & 1044 & 1349 & 1197 & & & & \\
\hline Intestinal caeca length & 1683 & 2306 & 1995 & & & & \\
\hline
\end{tabular}

$*=$ percentage of body-length, $\mu \mathrm{m}=$ Micron

Table 2: Numbers, rows and dimensions of body spines on different regions of current specimens

\begin{tabular}{|l|c|c|c|c|c|c|c|c|c|}
\hline \multirow{2}{*}{ Spines } & \multicolumn{3}{|c|}{ Number } & \multicolumn{3}{c|}{ Spine length $(\mu \mathrm{m})$} & \multicolumn{3}{c|}{ Spine width $(\mu \mathrm{m})$} \\
\cline { 2 - 11 } & min. & Max. & mean & min. & Max. & mean & min. & Max. & Mean \\
\hline Oral spine numbers & & & & & & & & & \\
$-\quad \quad$ 1st row & 31 & 33 & 32 & 24 & 30 & 27 & 13 & 16 & 15 \\
- $\quad$ 2nd row & 32 & 33 & 32 & 27 & 31 & 29 & 13 & 15 & 14 \\
\hline Other body spines rows:- & & & & & & & & & \\
- At anterior region & 40 & 43 & 42 & 6 & 8 & 7 & 7 & 9 & 8 \\
$-\quad$ At median region & 39 & 42 & 41 & 10 & 13 & 12 & 6 & 7 & 7 \\
$-\quad$ At posterior region & 22 & 26 & 24 & 4 & 7 & 6 & 3 & 5 & 4 \\
\hline
\end{tabular}


Table 3: Comparison of the dimensions and measurements of current specimen and previously described forms. Dimensions are in $\mathrm{mm}$.

\begin{tabular}{|c|c|c|c|c|}
\hline Source (Reference) & Manter (1940) & Manter (1963) & Mago\& Chinchilla (2002) & Current research \\
\hline Host Name & Balistes 'Verres & $\begin{array}{c}\text { Balistesaculeatus; } \\
\text { B. capriscus\& B. verres }\end{array}$ & Balistesvetula & Balistoidesviridescens \\
\hline Host Number & 1 & NotMentioned & 2 & 2 \\
\hline Host Locality & $\begin{array}{c}\text { James Island, } \\
\text { Galapagos }\end{array}$ & $\begin{array}{c}\text { Bermuda Islands, } \\
\text { Puerto Vallarta, Jalisco and } \\
\text { Red Sea.. }\end{array}$ & Mochima Bay & $\begin{array}{l}\text { (Sharm EL-Naga) } \\
\text { Safaga-Red sea }\end{array}$ \\
\hline Parasite Number & 2 & Not mentioned & 4 & 7 \\
\hline $\begin{array}{l}\text { Parasite Location } \\
\text { (habitat) }\end{array}$ & Intestine & Intestine & Intestine & $\begin{array}{c}\text { Small Intestine } \\
\left(3^{\text {rd }} \text { part of Ileum }\right)\end{array}$ \\
\hline \multicolumn{5}{|c|}{ Dimension and Measurements (mm) } \\
\hline Length & $1.957-2.794$ & $1.35-4.61$ & $0.995-1.575(1.785)$ & $2.479-3.200(2.840)$ \\
\hline $\begin{array}{l}\text { Width (Widest } \\
\text { region) }\end{array}$ & $0.945-1.093$ & $0.440-1.093$ & $0.560-0.595(0.560)$ & $0.968-1.006(0.987)$ \\
\hline Fore body length & $0.712-1.161$ & Not mentioned & Not mentioned & $0.848-1.019(0.934)$ \\
\hline Oral sucker length & $0.275-0.307$ & $0.110-0.275$ & $0.144-0.225(0.183)$ & $0.132-0.175(0.154)$ \\
\hline Oral sucker width & & $0.200-0.307$ & $0.180-0.243(0.212)$ & $0.286-0.317(0.302)$ \\
\hline Prepharynx length & $0.142-0.315$ & Not mentioned & Not mentioned & $0.162-0.230(0.196)$ \\
\hline Pharynx length & $0.232-0.277$ & $0.090-0.277$ & $0.135-0.180(0.156)$ & $0.365-0.372(0.369)$ \\
\hline Pharynx width & $0.225-0.262$ & $0.110-0.262$ & $0.135-0.189(0.159)$ & $0.231-0.325(0.278)$ \\
\hline Esophagus length & very short & short & $0.018-0.027(0.024)$ & $0.016-0.027(0.022)$ \\
\hline Ventral sucker length & $0.300-0.360$ & $0.210-0.300$ & $0.243-0.306(0.261)$ & $0.395-0.409(0.402)$ \\
\hline Ventral sucker width & & $0.274-0.360$ & $0.243-0.315(0.273)$ & $0.347-0.387(0.367)$ \\
\hline Ovary length & Not mentioned & $0.148-0.210$ & $0.099-0.144(0.120)$ & $0.173-0.203(0.188)$ \\
\hline Ovary width & Not mentioned & $0.114-0.210$ & $0.135-0.171(0.150)$ & $0.229-0.266(0.248)$ \\
\hline Anterior testis length & Not mentioned & $0.170-0.210$ & $0.198-0.306(0.255)$ & $0.249-0.412(0.331)$ \\
\hline Anterior testis width & Not mentioned & $0.230-0.323$ & $0.225-0.342(0.276)$ & $0.243-0.318(0.281)$ \\
\hline Posterior testis length & Not mentioned & $0.150-0.220$ & $0.234-0.324(0.291)$ & $0.311-0.455(0.383)$ \\
\hline Posterior testis width & Not mentioned & $0.230-0.334$ & $0.189-0.315(0.255)$ & $0.221-0.369(0.295)$ \\
\hline $\begin{array}{l}\text { Post-testicular } \\
\text { distance }\end{array}$ & $0.285-0.465$ & Not mentioned & Not mentioned & $0.344-0.456(0.400)$ \\
\hline Egg length & $0.060-0.070$ & $0.060-0.080$ & $0.043-0.080$ & $0.068-0.081(0.075)$ \\
\hline Egg width & $0.031-0.037$ & $0.031-0.050$ & $0.018-0.053$ & $0.041-0.050(0.046)$ \\
\hline Body spines length & Not mentioned & 0.015 & $0.010-0.130(0.012)$ & $0.010-0.013(0.012)$ \\
\hline Body spines width & Not mentioned & 0.004 & $0.003-0.005(0.004)$ & $0.006-0.007(0.007)$ \\
\hline Sucker length ratio & \multirow[t]{2}{*}{$1: 1.09-1.17$} & $1: 1.29$ & $1: 1.20-1.69(1.40)$ & $1: 2.34-2.99(2.67)$ \\
\hline Sucker width ratio & & $1: 1.15-2.20$ & $1: 1.17-1.45(1.34)$ & $1: 1.21$ \\
\hline
\end{tabular}

Measurements and dimensions are in millimeters, $\mathrm{mm}=$ millimeter 
Table 4: Dimensions, measurements and ratios of Pseudolepidapedon balistis (biological variant).

\begin{tabular}{|c|c|c|c|c|c|c|c|}
\hline Dimension and measurements $(\mu \mathrm{m})$ & Min. & Max. & Mean & Ratios & Min. & Max. & Mean \\
\hline Length & 2348 & 2355 & 2352 & Width \%* & 24 & 25 & 24.5 \\
\hline Width (Widest region) & 585 & 593 & 589 & Fore body $\% *$ & 36.6 & 36.7 & 36.7 \\
\hline Width at level of: & & & & Hind body length $\% *$ & 51.8 & 52 & 51.9 \\
\hline - Under oral sucker directly & 160 & 163 & 162 & Sucker length ratio & $1: 2$ & $1: 2.1$ & $1: 2.1$ \\
\hline - $\quad$ Pharynx & 303 & 309 & 306 & Sucker width ratio & $1: 1.1$ & $1: 1.9$ & $1: 1.5$ \\
\hline - Ventral sucker & 439 & 445 & 443 & Oral sucker length $\%^{*}$ & 4.9 & 5 & 5 \\
\hline - Ovary & 584 & 589 & 587 & Ventral sucker length\%* & 10 & 10.1 & 10.1 \\
\hline - Anterior testis & 574 & 579 & 577 & Oral sucker length/ Width ratio & $1: 1.5$ & $1: 1.6$ & $1: 1.6$ \\
\hline - Posterior testis & 534 & 537 & 536 & Ventral sucker length/ Width ratio & $1: 0.88$ & $1: 0.88$ & $1: 0.88$ \\
\hline Fore body length & 860 & 865 & 863 & Sucker total length $\% *$ & 14.9 & 15.1 & 15 \\
\hline Hind body length & 1217 & 1225 & 1221 & Oral sucker length/ Pharynx length ratio & $1: 2$ & $1: 2$ & $1: 2$ \\
\hline Oral sucker length & 114 & 117 & 116 & Ventral sucker length/ pharynx length ratio & $1: 1$ & $1: 1$ & $1: 1$ \\
\hline Oral sucker width & 173 & 188 & 181 & Prepharynx length $\% *$ & 11.3 & 11.5 & 11.4 \\
\hline Prepharynx length & 265 & 271 & 268 & Pharynx length $\% *$ & 9.8 & 10 & 9.9 \\
\hline Pharynx length & 230 & 236 & 233 & Anterior testis length $\% *$ & 10.2 & 10.4 & 10.3 \\
\hline Pharynx width & 173 & 180 & 177 & Anterior testis length/ Width ratio & $1: 1.16$ & $1: 1.18$ & $1: 1.17$ \\
\hline Esophagus length & 27 & 34 & 31 & Posterior testis length $\% *$ & 12.8 & 13.1 & 13 \\
\hline Precaecal sacs & 0 & 0 & 0 & Posterior testis length/ Width ratio & $1: 0.80$ & $1: 0.81$ & $1: 0.81$ \\
\hline Intestinal bifurcation to ventral sucker & 83 & 88 & 86 & Ovary length $\% *$ & 6.5 & 6.6 & 6.6 \\
\hline Genital pore to ventral sucker & 0 & 5 & 3 & Ovary length/ Width ratio & $1: 1.25$ & $1: 1.27$ & $1: 1.26$ \\
\hline Ventral sucker length & 235 & 239 & 237 & Ventral sucker to ovary $\% *$ & 14.3 & 14.4 & 14.4 \\
\hline Ventral sucker width & 206 & 211 & 209 & Distance between testes $\% *$ & 0.2 & 0.3 & 0.3 \\
\hline Ventral sucker to ovary & 335 & 338 & 337 & Post-testicular distance $\% *$ & 12 & 12.1 & 12.1 \\
\hline Ovary length & 152 & 155 & 154 & Prepharynx distance $\% *$ & 15.8 & 16 & 15.9 \\
\hline Ovary width & 191 & 195 & 193 & Prebifurcation distance $\% *$ & 25.6 & 25.7 & 25.7 \\
\hline Ovary to anterior testis & 3 & 5 & 4 & Oral to ventral sucker distance $\% *$ & 34.5 & 34.7 & 34.6 \\
\hline Anterior testis length & 239 & 244 & 242 & Previtelline distance $\% *$ & 24.2 & 28.4 & 26.3 \\
\hline Anterior testis width & 279 & 284 & 282 & Pre-genital pore distance $\% *$ & 29.2 & 29.3 & 29.3 \\
\hline Distance between testes & 4 & 7 & 6 & Preovarian distance $\% *$ & 43.8 & 44 & 43.9 \\
\hline Posterior testis length & 300 & 309 & 305 & Post-uterine distance $\%^{*}$ & 37.9 & 38 & 40 \\
\hline Posterior testis width & 244 & 247 & 246 & \multirow[t]{13}{*}{ Intestinal caeca length $\% *$} & 67.5 & \multirow[t]{13}{*}{67.5} & 67.5 \\
\hline Post-testicular distance & 281 & 285 & 283 & & & & \\
\hline Post-vitelline region length & 9 & 12 & 11 & & & & \\
\hline Egg length & 74 & 88 & 81 & & & & \\
\hline Egg width & 44 & 52 & 48 & & & & \\
\hline Prepharyngeal distance & 372 & 377 & 375 & & & & \\
\hline Prebifurcal distance & 601 & 605 & 603 & & & & \\
\hline Oral to ventral sucker distance & 810 & 817 & 814 & & & & \\
\hline Pre-genital pore distance & 685 & 691 & 688 & & & & \\
\hline Previtelline distance & 661 & 668 & 665 & & & & \\
\hline Preovarian distance & 1029 & 1036 & 1033 & & & & \\
\hline Post-uterine distance & 889 & 894 & 8912 & & & & \\
\hline Intestinal caeca length & 1584 & 1589 & 1587 & & & & \\
\hline
\end{tabular}




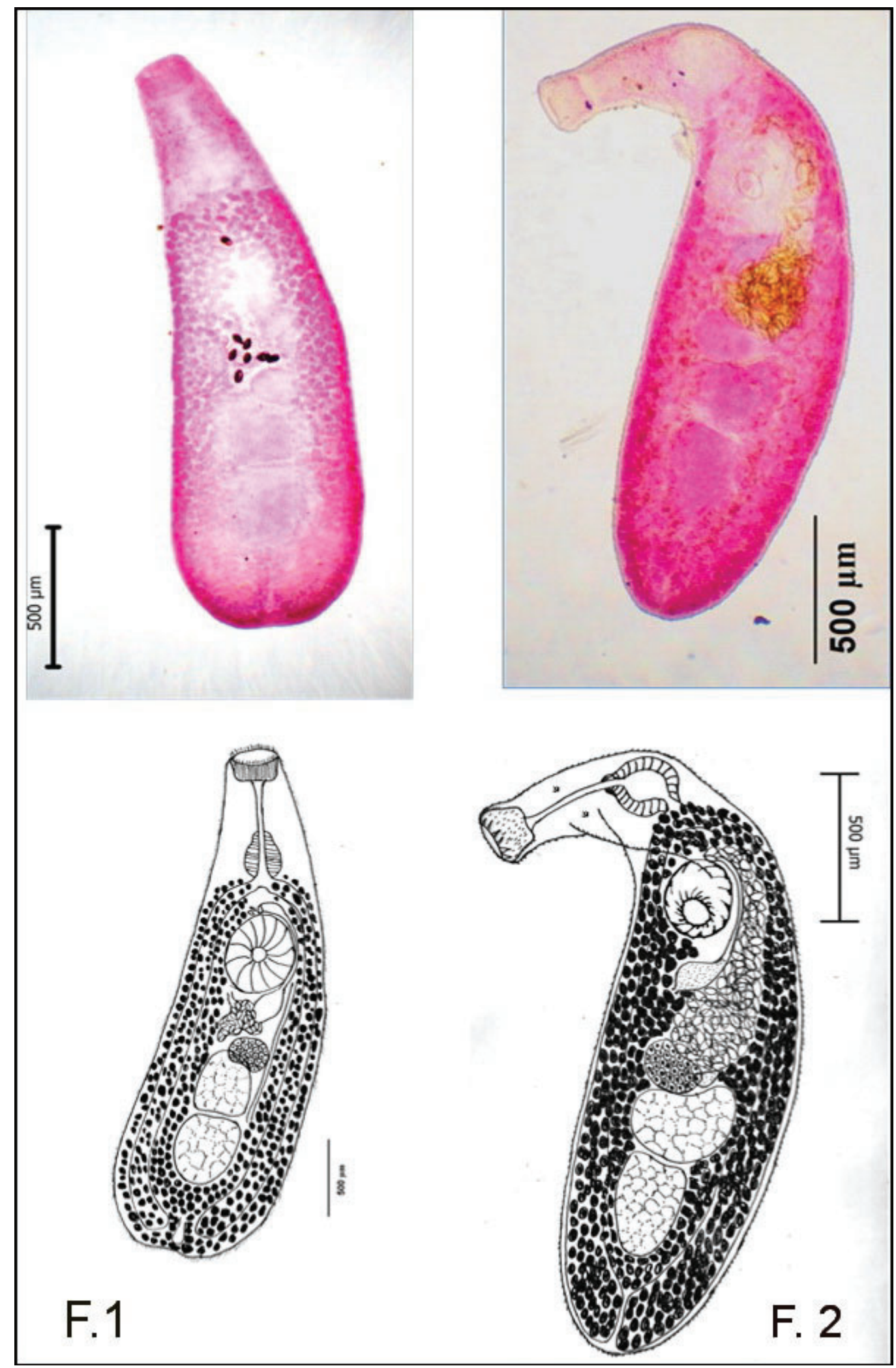

Fig. 1: Ventral view of adultPseudolepidapedon balistis Manter, 1940

Fig. 2: Ventral view of adultPseudolepidapedon balistis (biological variant) 


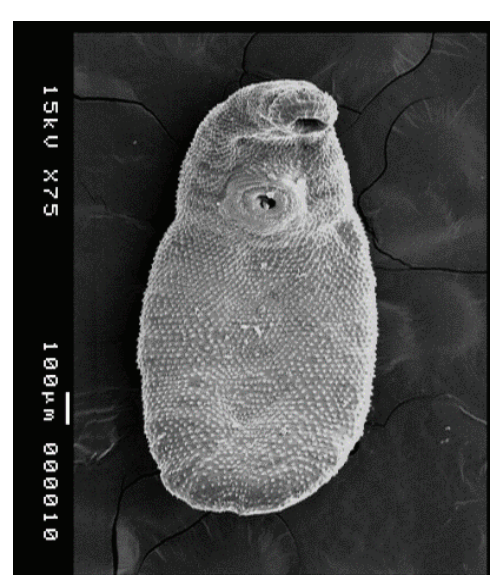

(A

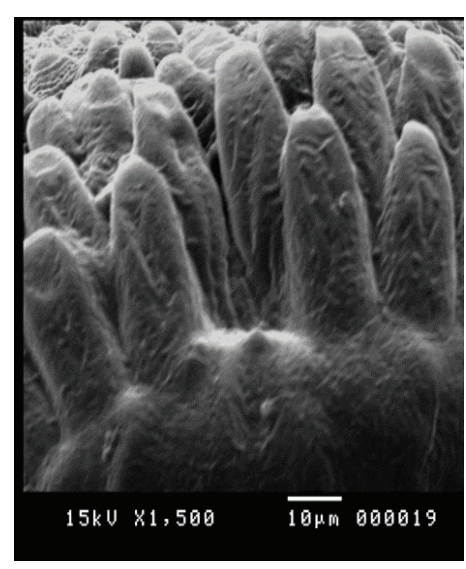

(D)

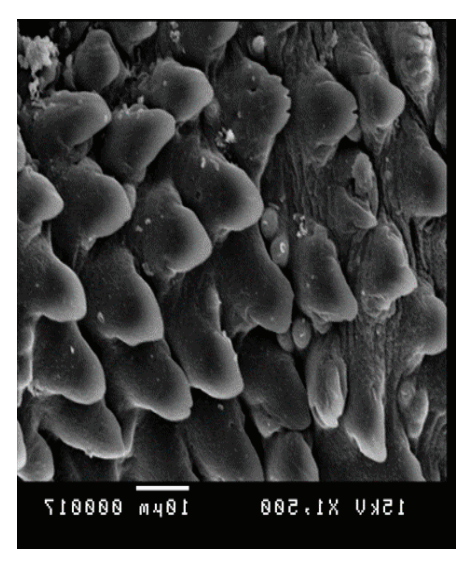

(G)

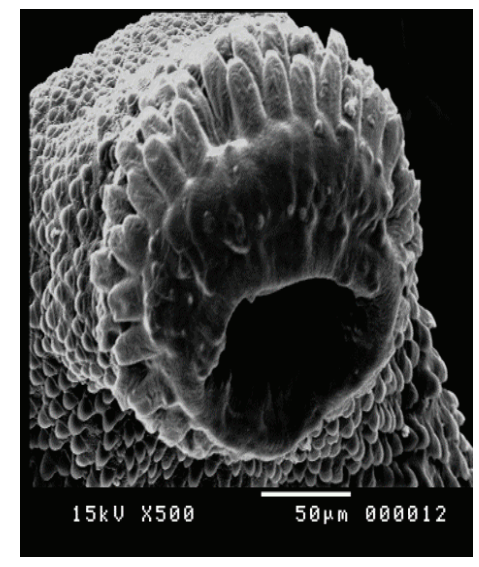

(B)

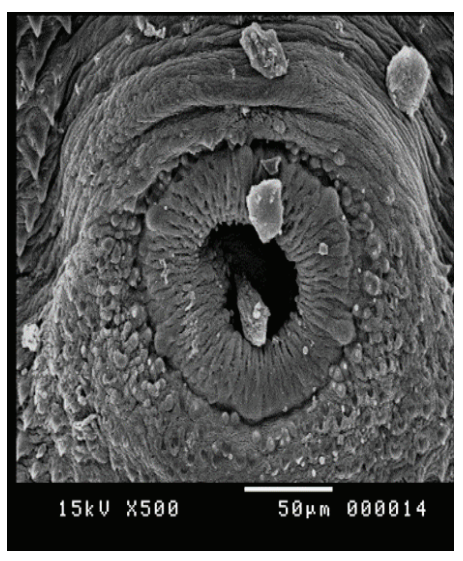

(E)

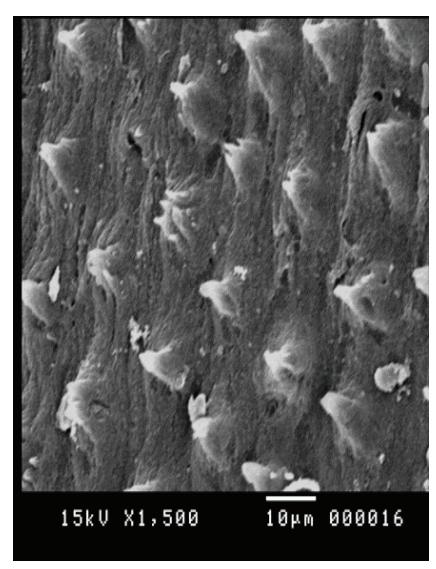

(H)

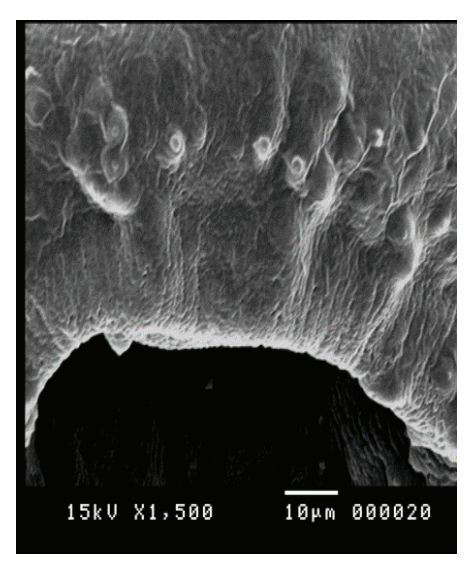

(C)

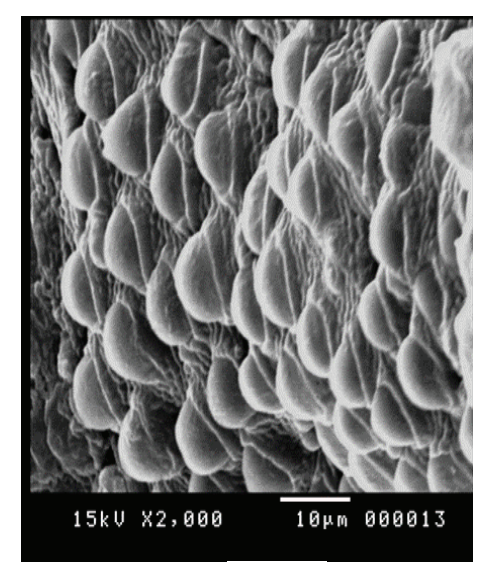

(F)

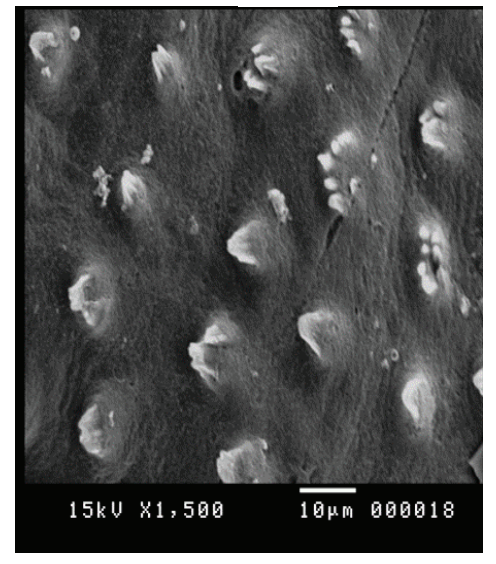

(I)

Plate 1: Scanning electron microscope of Pseudolepidapedon balistis 